\title{
Učinkovita komunikacija i rješavanje sukoba između medicinske sestre i pacijenta
}

1 Jasmina Starc

1 Fakulteta za zdravstvene vede Novo mesto, Slovenija

\section{Sažetak}

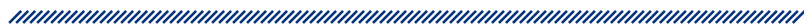

Komunikacija je važan dio pružanja zdravstvene zaštite. Dovodi do viših i boljih standarda pružanja zdravstvene zaštite. Medicinska sestra provodi mnogo vremena komunicirajući s pacijentima. Globalni je cilj njezine profesionalne komunikacije s pacijentima odnos u kojem će im omogućiti da bez straha i oklijevanja javljaju svoje potrebe, želje i očekivanja. Dobra komunikacija između medicinske sestre i pacijenata sama je po sebi korisna terapijska intervencija jer pacijentima pomaže da izraze svoje psihološke i emocionalne potrebe, postavljaju pitanja i osiguravaju veću uključenost u proces liječenja, steknu osjećaj da imaju kontrolu nad vlastitim zdravljem i liječenjem, razvijaju povjerenje i poštovanje u procesu ozdravljenja i steknu fizičko zdravlje. Ipak, u komunikaciji između medicinske sestre i pacijenata dolazi do problema, što može dovesti do sukoba. Iz perspektive medicinske sestre najčešći su uzroci sukoba nedostatak samosvijesti i neusklađena komunikacija s pacijentom. Iz perspektive pacijenata najčešći su uzroci sukoba njihov strah, nemogućnost da se izraze, nedostatak razumijevanja informacija i uputa te kriva očekivanja. U ovom prilogu prikazani su rezultati istraživanja u kojem smo proučavali iskustva pacijenata u komunikaciji s medicinskim sestrama. Zaključili smo da

je za 59 \% ispitanika komunikacija s medicinskom sestrom važna odnosno vrlo važna. Njih $85 \%$ vjeruje da je komunikacija između pacijenata i medicinskih sestara često ili uvijek prikladna zbog poštovanja, ljubaznosti i povjerenja. Više od $10 \%$ ispitanika već je bilo u sukobima s medicinskim sestrama, koji su riješeni mirnim dijalogom, isprikom, pa čak i uzvišenjem glasa. Međutim, svjesni su da je najbolja aktivnost za smanjenje sukoba strpljenje svih uključenih.

Ključne riječi: pacijent, medicinska sestra, komunikacija, sukob

Datum primitka: 02.04.2016.

Datum prihvaćanja: 30.11.2016.

Adresa za dopisivanje:

izv. prof. dr. sc. Jasmina Starc

Fakulteta za zdravstvene vede Novo mesto

Na Loko 2, 8000 Novo mesto, Slovenija

E-pošta: jasmina.starc@guest.arnes.si 


\section{Uvod}

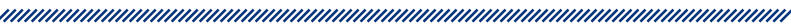

Komunikacija u području zdravstva od velike je važnosti jer o njoj ovisi odvijanje i način liječenja pacijenta, njegovo zadovoljstvo i neposredno također njegovo zdravstveno stanje. Komunikacija s pacijentom počinje čim pacijent uđe u zdravstvenu ustanovu. Pri tome je važno da medicinska sestra ima iskustvo u području komunikacije, da je u stanju aktivno slušati i promatrati pacijenta. Komunikacija je vrlo važna u zdravstvu, ali joj, nažalost, često obraćamo premalo pažnje, zanemarujemo je, a ponekad čak ispustimo ${ }^{1}$. Razlozi tome mogu biti preopterećenje medicinske sestre, nedostatak vremena i umor.

Medicinska se sestra svaki dan u svojem radu susreće s pacijentima. U kontaktu je s pacijentom od početka liječenja, tijekom i sve do završetka liječenja te je ujedno prilikom liječenja prisutna mnogo vremena, pa je stoga još toliko važniji način na koji se odvija njezina komunikacija. Njezin je zadatak da s pomoću učinkovite komunikacije s pacijentima uspostavi topao, pristojan i povjerljiv odnos. Pacijentovo zadovoljstvo u velikoj je mjeri povezano s komunikacijskim vještinama medicinske sestre ${ }^{2}$. Istraživanja su pokazala da je zadovoljstvo pacijenata povezano sa sposobnošću medicinske sestre da odražava i iskazuje toplinu, emocionalnu podršku, razumijevanje, brigu i dostupnost pacijentu. U svojem posla ona se susreće $s$ različitim pacijentima pa je stoga važno da ima dobro razvijene komunikacijske vještine koje joj također pomažu u sukobima.

Medicinska sestra mora svakog pacijenta tretirati individualno i sudjelovati u procesu liječenja kao član medicinskog tima, jer svaki pacijent ima drugačije osobne karakteristike, sposobnosti, znanje, različitu motivaciju za liječenje, kao i različite želje povezane s liječenjem. Posebnosti komunikacije proizlaze prvenstveno iz etičkih principa, odnosno iz poštivanja osobnosti pacijenta, njegovih prava i dužnosti, njegove kulture, starosti, bolesti i stupnja invaliditeta. Medicinska sestra mora dobiti što više informacija o pacijentu jer će na taj način saznati što pacijent želi i tako s njime postići najučinkovitiju komunikaciju ${ }^{3}$. Kvalitetna komunikacija između medicinske sestre i pacijenta može utjecati na pozitivniji stav pacijenata u procesu liječenja.

U samoj komunikaciji između medicinske sestre i pacijenta slušanje je također od velike važnosti. Kada pacijent dobro sluša, tada medicinska sestra o njemu dobi- va informacije. Pogrešno je misliti da svatko zna slušati. Kada slušamo pacijenta, potrošimo mnogo vremena, više nego za govor ili pisanje. Medicinska sestra također je savjetnica koja mora kroz različite pristupe i vještine koje posjeduje objasniti kakvi su problemi i zbog čega je do njih došlo. Pacijentu mora prosljeđivati informacije u odnosu na potrebe i interes.

Budući da medicinska sestra na radnom mjestu provodi mnogo vremena, stalno je uključena u proces komunikacije $s$ kolegama ili pacijentima, tako da je potencijal za nastanak sukoba velik. Medicinska sestra mora biti u stanju prilagođavati se, popuštati i zajedno s pacijentom tražiti najbolja moguća rješenja za njega, dakle mora biti u stanju postizati kompromise. Važno je da u tom području ima iskustva te da je u sukobima u stanju pravilno reagirati. Za bolje i lakše prepoznavanje sukoba korisno je ako medicinska sestra može razlikovati vrste ili dijelove sukoba ${ }^{4}$. U sukobu mogu nastati pozitivne ili negativne posljedice, koje mogu poboljšati odnos s pacijentom, no mogu ga i uništiti. Važno je da medicinske sestre iz svakog sukoba nešto nauče i spriječe njihovo ponavljanje.

\section{Komunikacija između medicinske sestre i pacijenta}

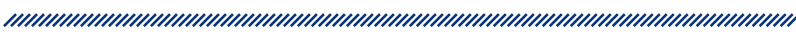

Komunikacija je važan dio pružanja zdravstvene zaštite. $U$ razvijenim su zemljama komunikacija i stjecanje interpersonalnih vještina u području zdravstva postali dio obrazovnog paketa. Uspješna komunikacija osnova je za pružanje zdravstvene zaštite. Dovodi do viših, boljih standarda pružanja zdravstvene zaštite ${ }^{5}$.

Mnogo teoretskih koncepata komunikacije medicinskih sestara proizlazi iz psiholoških teorija. Teorije o zdravstvenoj njezi uključuju profesionalnu komunikaciju kao uvjet i važan dio stručnog rada medicinske sestre. Sve humanističke teorije definiraju zdravstvenu njegu kao ljudski odgovor. Zdravstvena njega poštuje ljudski potencijal u svakom pojedincu. Riječ je o odnosu između medicinske sestre i pacijenta. Oboje su prisutni cijelom osobnošću. Biti s nekim nešto je posve drugo nego raditi za nekoga. Taj odnos moramo istražiti i njegovati. Oboje su u odnosu jednakovrijedni i mogu nešto pridonijeti jedno drugome ${ }^{6}$. 
Pacijenti imaju pravo na kvalitetnu komunikaciju. Već iz perspektive zaštite podataka moramo obratiti posebnu pozornost komunikaciji između zdravstvenih djelatnika, kao i između zdravstvenih djelatnika s trećim osobama o pacijentu, njegovim podatcima i njegovim zdravstvenim stanjem ${ }^{7}$. U Sloveniji pacijent ima pravo na to da zdravstveni djelatnici i zdravstveno osoblje s njim razgovaraju ili drugačije komuniciraju na slovenskom jeziku ili jeziku nacionalne zajednice na području mjesnih zajednica gdje je osim slovenskog jezika službeni jezik također talijanski odnosno mađarski jezik, međutim liječnik mora kod osobe koja ne zna slovenski jezik također ispuniti svoju dužnost objašnjavanja i steći njezin pristanak na liječničku intervenciju. Pacijent koji ne može komunicirati na slovenskom jeziku ne bi trebao biti lišen medicinske pomoći. Važno je da pacijentu prosljeđujemo sveobuhvatne informacije o zdravstvenom stanju i liječenju u izravnom kontaktu, što obzirnije i na način razumljiv za pacijenta.

Posebnosti komunikacije u zdravstvu proizlaze prvenstveno iz etičkih principa, odnosno iz poštivanja osobnosti pacijenta, njegovih prava i dužnosti, njegove kulture, starosti, bolesti i stupnja invaliditeta. Pacijenti od svih zdravstvenih djelatnika očekuju da će biti tretirani i liječeni na najprikladniji način. Očekuju da će biti tretirani i liječeni na siguran način i da će im zdravstveni djelatnici posvetiti dovoljno vremena ${ }^{8}$. Odnos pacijenta i medicinske sestre odražava se putem komunikacije, pogotovo neverbalne. Pacijenti koji su vrlo bolesni mogu slušati samo napola, odnosno neke riječi čak propuste. Takva ograničenja prekidaju kontakt između pacijenta i medicinske sestre, a time i mogućnost sudjelovanja. $U$ radu s pacijentima potrebno je zadržati ljudskost, brigu za drugog, povjerenje i suosjećanje. Događa se naime da se s pacijentima govori na jeziku koji ne razumiju, odnosno na latinskom jeziku, a ponekad i na engleskom. Prilikom toga medicinska se sestra mora dignuti ili spustiti na razinu pacijenta. Potrebno je obratiti pozornost na činjenicu da pacijent ne bude ponižen izravnim pitanjima. Komunikacija je važna da bi pacijent prihvatio upute i savjete. Za stvaranje dobrog odnosa između pacijenta i medicinske sestre potrebno je osjetljivo i kompetentno vođenje razgovora, što smanjuje rizik od nastanka nesporazuma i problema u komunikaciji. Kompetentno vođenje razgovora znači biti ljubazan, brižan, empatičan i u stanju slušati pacijenta ${ }^{9}$. Tako možemo postići globalni cilj profesionalne komunikacije medicinske sestre s pacijentom - odnos u kojem će pacijent bez straha i oklijevanja priopćavati svoje potrebe, želje i očekivanja. Medicinska će sestra također biti u stanju lakše otkrivati razlike između pacijenata ako će s njima više razgovarati te ih posebno aktivnije slušati ${ }^{10}$.

Medicinske sestre imaju postavljene određene standarde za komunikaciju koje je potrebno poštivati ${ }^{11}$ : moraju komunicirati sigurno i učinkovito, izgraditi terapeutski odnos i komunicirati s pacijentom kao s jedinstvenom osobom, moraju primjenjivati verbalnu i neverbalnu komunikaciju, komunikaciju putem pisanja i tehnologiju za komuniciranje, prihvatiti potrebu za razumijevanjem, promicati osobnu zaštitu, održavati točne, jasne, potpune pisane i elektroničke zapise te poštivati i štititi osobne podatke pacijenta.

Može se dodati da su razina, način i opseg komunikacije u procesu zdravstvene njege ovisni o svim sudionicima. $U$ odnosu između zdrave i bolesne osobe medicinska se sestra mora prilagođavati. To se odnosi na ponašanje u komunikaciji, način govora, količinu informacija i korištenje raznim sredstvima komunikacije. Standardni su ciljevi za njegu koje medicinska sestra pritom slijedi: atmosfera u kojoj se razvija komunikacija; podrška i pomoć u poremećajima komunikacije i zamjensko preuzimanje funkcija koje nedostaju u komunikacijskom lancu.

Za kulturu odnosa između medicinske sestre i pacijenata nije dovoljno samo željeti, nego su također potrebni znanje i fleksibilnost. Neke studije, primjerice, pokazuju da pacijenti ne razumiju čak $50 \%$ od onoga što im zdravstveni djelatnici govore ${ }^{10}$. To prekida kontakt i mogućnost sudjelovanja. Zdravstveni bi se djelatnici trebali koristiti razumljivijim jezikom s manje latinskih izraza i uglavnom bez stranih riječi, a prilikom komunikacije s djecom čak dijalektom, kao i žargonom koji dijete razumije. Međutim, autorica pritom upozorava na vremensko ograničenje koje se povećava. Prema tome, osobni su kontakti ograničeni na minimalno vrijeme, što još više tereti odnose u zdravstvu.

U profesionalnoj komunikaciji medicinska sestra osim znanja iz teorije zdravstvene njege također mora poznavati i samu sebe ${ }^{6}$. Poznavanje samog sebe odnosno slika o sebi samom primjetan je aspekt vlastite osobnosti. Sliku o samom sebi odnosno samopoštovanje prikazuju uloge koje imamo u životu, u svojim odnosima s drugim ljudima. Izražavaju se u socijalnim i poslovnim situacijama. Kada smo dosljedni u svojem doživljavanju s doživljavanjima drugih, zadovoljni smo, inače smo u nevolji. Razumijevanje sebe i dijalog sa sobom temelj je za uspješnu interakciju s drugima. Učenje i razmišljanje o samopoštovanju pruža medicinskoj sestri veću fleksibilnost i prikladnost u odnosima s drugim ljudima. 
Kad medicinska sestra i pacijent uspostave dobar međusobni odnos, to oboma predstavlja priliku za rast i razvoj. Interpersonalni odnos između medicinske sestre i pacijenta razvija se u četiri faze ${ }^{12}$ : (1) faza orijentacije počinje kada pacijent izražava potrebu za profesionalnom pomoći, (2) faza identifikacije počinje kada pacijent postane svjestan svoje bolesti i onoga što se s njim događa, (3) interakcijska faza u kojoj je pacijent već formirao sliku o svojoj bolesti i (4) faza rješavanja u kojoj se pacijent sprema na odlazak kući.

Dobra komunikacija između medicinske sestre i pacijenta sama je po sebi korisna terapeutska intervencija pa je stoga možemo ubrajati u zdravstvenu njegu pacijenta. Komunikacija u zdravstvu pomaže pacijentu izraziti psihološke i emocionalne potrebe, postavljati pitanja i osigurati veću uključenost u skrb koja mu se pruža, steći osjećaj da ima kontrolu nad vlastitim zdravljem i liječenjem, razvijati povjerenje i poštovanje u procesu liječenja i steći fizičko zdravlje, kao npr. smanjenje boli i smanjenje krvnog tlaka ${ }^{11}$.

\section{Rješavanje sukoba između medicinske sestre i pacijenta}

Pacijenti često imaju osjećaj da su podređeni liječniku odnosno medicinskoj sestri. Baš zbog osjećaja bespomoćnosti slabo sudjeluju u procesu liječenja. Pacijent se pasivno prepušta odlukama medicinske sestre i liječnika ${ }^{13}$. Međutim, često se događa da se u procesu komunikacije pojavljuju šumovi u komunikaciji koji otežavaju sam proces. U poremećaje u komunikaciji ubrajaju se poremećaji kod pošiljatelja poruke (odašiljač), smetnje u prijenosu poruke i smetnje kod primatelja poruke (prijamnik $)^{14}$. Najčešći su šumovi u komunikaciji između medicinske sestre i pacijenta u kojoj medicinska sestra nastupa kao pošiljatelj: ravnodušnost, pogrešno protumačene poruke, vlastita nesigurnost, podcjenjivanje važnosti informacija za pacijenta, strah od pitanja rođaka, pogrešna tumačenja, nejasno i zbunjujuće razgovaranje, nedostatak kontakta i vremensko ograničenje ${ }^{15}$. Poremećaji se mogu pojaviti i na strani pacijenta koji također nastupa kao pošiljatelj. Ti su poremećaji: nesposobnost pacijenta da se izrazi, skrivene izjave, strah od odgovaranja, strah od autoriteta, pogrešno očekivanje, sram, osjećaji krivnje, osjećaji dužnosti, depresija i agresija ${ }^{10}$. Najčešći su šumovi u komunikaciji između medicinske sestre i pacijenta u kojoj pacijent nastupa kao primatelj: duhovna pasivnost, oštećenje sluha, emocije (ljutnja, strah), nedostatak pažnje, glasna i zbunjujuća okolina, pogrešna tumačenja, neposlušnost i strah od pitanja ${ }^{15}$. U procesu komunikacije medicinska sestra također nastupa kao primatelj. U tom se slučaju kod nje mogu pojaviti sljedeći poremećaji: ravnodušnost, nedostatak vremena, neprikladan odnos, stereotipni odgovori, neiskrenost, neprikladno odazivanje, uzimanje hrabrosti izvođenjem gesta i mimikom ${ }^{10}$. Svi spomenuti poremećaji mogu između ostalog također dovesti do sukoba.

Posljedice sukoba mogu se podijeliti u dvije kategorije. Prva kategorija uključuje posljedice uspješno riješenog sukoba, to su pozitivne posljedice jer omogućuju sudjelovanje te ga čak poboljšavaju. U drugoj su kategoriji posljedice neriješenih sukoba, koje uključuju posljedice sukoba koje smo rješavali, ali smo pritom bili neuspješni. Posljedice neriješenog konflikta obično su negativne jer ne pridonose poboljšanju radnog procesa i međusobnih odnosa ${ }^{16}$. Ako ne postoji interes za rješavanje sukoba i pojedinci ostaju pri svome, sukob se samo produbljuje ${ }^{17}$. Sve to utječe na pojedinca i na atmosferu u timu, a time i na radne procese $\mathrm{e}^{18}$.

\section{Metodologija}

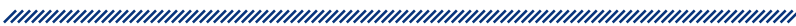

\subsection{Svrha i ciljevi istraživanja}

Svrha je istraživanja predstaviti i ispitati kako pacijenti doživljavaju proces komunikacije između medicinskih sestara i pacijenata, kao i uzroke za nastanak sukoba između njih.

Ciljevi su istraživanja:

- ustanoviti kako se često odnosno koliko puta godišnje pacijenti susreću s medicinskim sestrama

- steći mišljenja pacijenata o iskustvima s komunikacijom između njih i medicinskih sestara

- ustanoviti kako su često odnosno koliko puta pacijenti bili u sukobu s medicinskim sestrama

- ispitati uzroke sukoba između medicinskih sestara i pacijenata koje pacijenti navode

- istražiti kako bi se mogli smanjiti sukobi između pacijenata i medicinskih sestara. 


\subsection{Istraživačka pitanja}

Postavili smo sljedeća istraživačka pitanja:

- Kako se često ispitanici kao pacijenti godišnje susreću s medicinskim sestrama?

- Kako ispitanici procjenjuju komunikaciju između medicinskih sestara i njih kao pacijenata?

- Što ispitanici smatraju da im je kao pacijentima važno u komunikaciji?

- Kako su često ispitanici kao pacijenti bili izloženi sukobu s medicinskim sestrama?

- Koje razloge ispitanici navode kao uzrok sukoba?

- Na koji su način ispitanici rješavali sukob?

- Kako ispitanici procjenjuju činitelje koji bi smanjili sukob između medicinskih sestara i njih kao pacijenata?

\subsection{Metode i tehnike prikupljanja podataka}

Istraživanje se temelji na kvantitativnoj metodi rada. Za pojašnjavanje i razumijevanje razmatrane teme primijenili smo deskriptivnu metodu. Podatci su prikupljeni tehnikom anketiranja. Primijenili smo upitnik s pitanjima zatvorenog tipa koji je formiran na temelju pregleda literature. Prvi dio pitanja odnosi se na demografske podatke ispitanika (spol, starost, stupanj obrazovanja, područje rada, učestalost susretanja s medicinskom sestrom). Drugi dio pitanja odnosi se na komunikaciju između medicinskih sestara i pacijenata, kakva su njihova iskustva i kako su zadovoljni s načinom komunikacije. Tvrdnje o načinu komunikacije pacijenti su označavali ocjenama od 1 do 3 , pri čemu je 1 - ne slažem se, 2 - djelomično se slažem i 3 - slažem se. Načine rješavanja sukoba pacijenti su označavali s pomoću 5-stupanjske skale stavova, pri čemu je 0 - nikada, 1 - vrlo rijetko, 2 - rijetko, 3 - često i 4 - uvijek. Treći dio pitanja odnosi se na razloge za nastanak sukoba u komunikaciji između medicinske sestre i pacijenta te prijedloge o tome kako poboljšati komunikaciju među njima. Činitelje koji bi smanjili sukobe između pacijenata i medicinskih sestara pacijenti su označavali s pomoću 4-stupanjske skale stavova, pri čemu je 0 - ne bi se smanjili, 1 - vrlo bi se rijetko smanjili, 2 - rijetko bi se smanjili i 3 - često bi se smanjili.

\subsection{Opis uzorka}

Uzorak koji smo zahvatili u istraživanju predstavlja populacija od 980 osoba, koja predstavlja pacijente, jer se svi nalazimo u ulozi pacijenta prilikom pregleda kod osobnog liječnika, specijalista, stomatologa itd., od toga 715 žena (73\%) i 265 muškaraca (27\%). Prema dobnoj strukturi u anketi je sudjelovalo $48 \%$ ispitanika u dobi od 21 do 30 godina, $20 \%$ ispitanika u dobi od 31 do 40 godina, zatim $12 \%$ u dobi do 20 . godina, $11 \%$ ispitanika u dobi između 41 i 50 godina, $6 \%$ u dobi od 51 do 60 godina i $3 \%$ onih koju za vrijeme anketiranja imali 61 godinu ili više. Nešto više od polovine ispitanika (58 \%) živi u ruralnim područjima, a ostalih $42 \%$ živi u raznim gradovima. Uzimajući u obzir stupanj obrazovanja gotovo polovina ispitanika ( $48 \%$ ) ima srednjoškolsko obrazovanje, a slijede ispitanici s visokoškolskim obrazovanjem kojih ima $23 \%, 16 \%$ ispitanika s fakultetskim obrazovanjem te ispitanici s višom školom (6\%) i s magisterijem (3\%). Najmanje ispitanika ima osnovnoškolsko obrazovanje (1\%) i doktorat (1\%). Većina ispitanika (47\%) zaposlena je u ekonomiji, $25 \%$ u javnom sektoru, $15 \%$ još se školuje, $9 \%$ je nezaposlenih i $4 \%$ u mirovini.

\subsection{Opis obrade podataka}

Podatci su bili obrađeni statističkim paketom SPSS 19.0. Izračunane su apsolutne i relativne frekvencije, a kod skala stavova prosječne ocjene. Istraživanje je provedeno putem internetskog upitnika www.1ka.si, pri čemu smo mrežnu poveznicu na anketu prosljeđivali putem e-pošte i objavili je na društvenim mrežama, gdje smo primijenili uzorkovanje metodom društvenih mreža - metodu snježne grude. Svi su ispitanici u istraživanju sudjelovali dobrovoljno i anonimno u veljači i u prvoj polovini ožujka 2016. U obzir smo uzeli sve etičke principe istraživanja i zaštite prikupljenih podataka (osobni podatci ispitanika nisu bili povezani s odgovorima, što je spriječilo identifikaciju s objavljenim rezultatima, a podatci su se isto tako upotrebljavali samo u svrhu istraživanja, a ne u buduće neistraživačke svrhe koje krše informacijsku dimenziju privatnosti).

\section{Rezultati}

S medicinskim se sestrama $42 \%$ ispitanika susreće nekoliko puta godišnje (5 do 6 puta), $30 \%$ jednom mjesečno, $4 \%$ tjedno i $24 \%$ jednom godišnje ili manje.

Da je komunikacija između medicinskih sestara i njih vrlo važna smatra $47 \%$ ispitanika, $40 \%$ vrlo nevažna, $12 \%$ važna, $1 \%$ nevažna. 


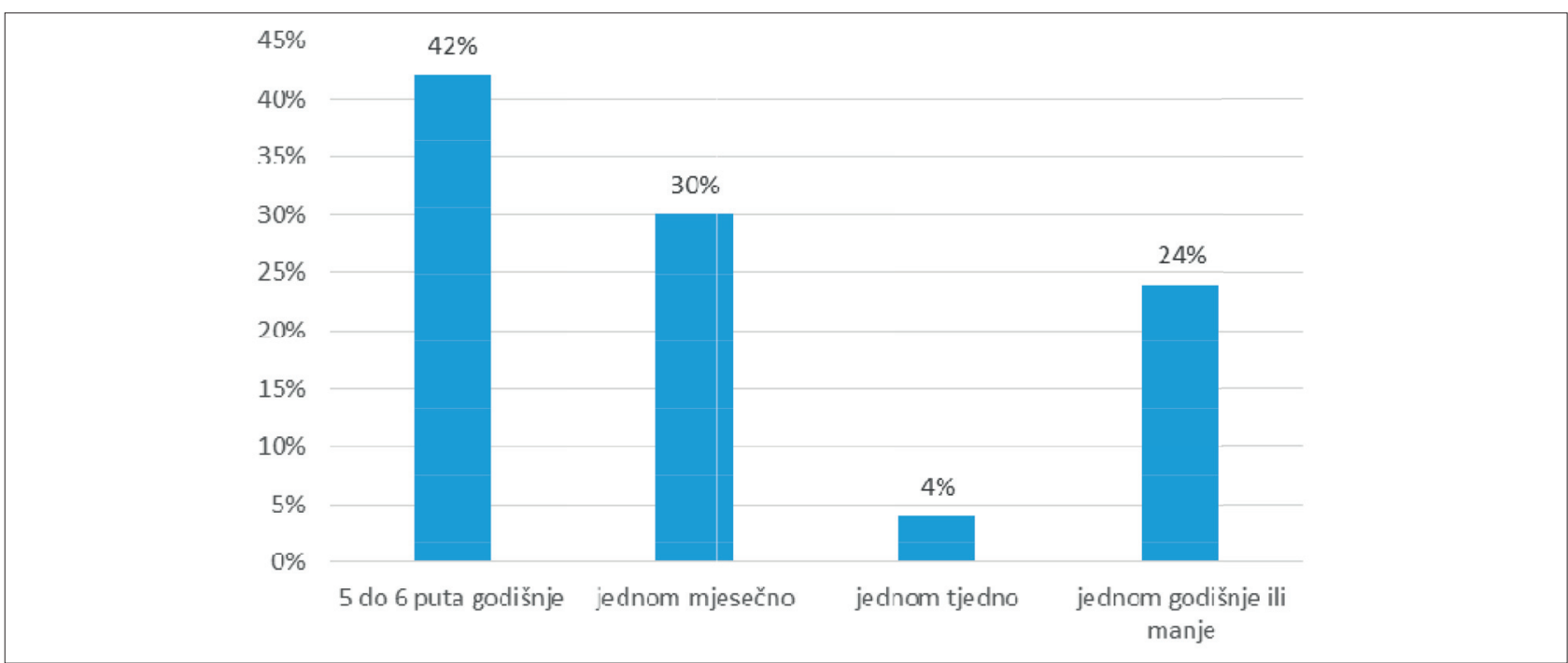

Slika 1. Učestalost susretanja s medicinskom sestrom $(\mathbf{N}=980)$

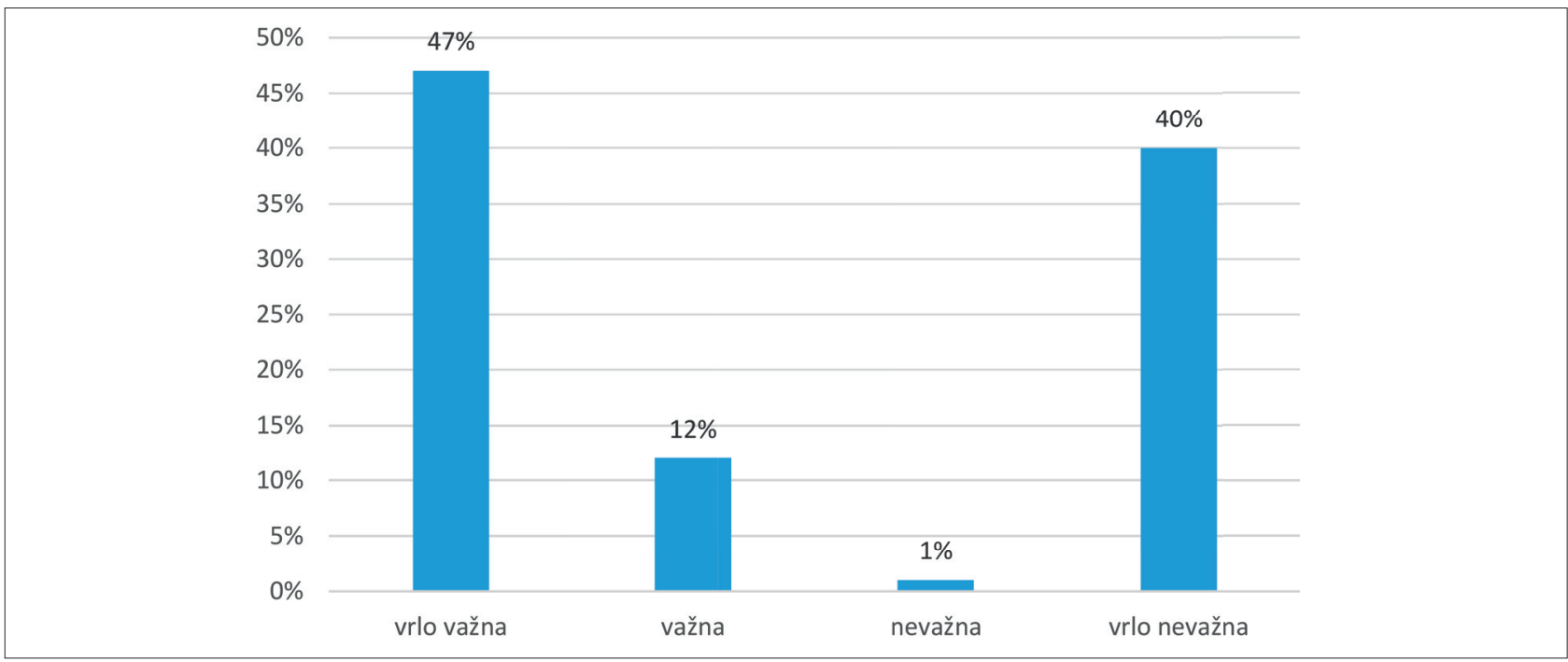

Slika 2. Važnost komunikacije između medicinske sestre i pacijenta $(\mathbf{N}=\mathbf{9 8 0})$

Kao činitelje uspješne komunikacije između njih i medicinskih sestara naveli su poštovanje ( $35 \%)$, ljubaznost (25\%), povjerenje (22\%), komunikativnost (7\%), empatiju (6 \%) i svladavanje sukoba (5\%).

U sukobu s medicinskim sestrama već je bilo $75 \%$ ispitanika, a $25 \%$ nije bilo.

Ispitanici kao razlog sukoba najčešće navode neprimjeran odnos, s njime se naime suočilo čak $87 \%$ ispitanika. Sljedeći su razlozi za sukob po učestalosti dugo čekanje ( $57 \%$ ispitanika), nesporazum (55\% ispitanika) i neprofesionalizam (54\% ispitanika). Zanimljivo je da mnogo ispitanika (76\%) smatra da rijetko dolaze u sukob zbog svoje preosjetljivosti zbog bolesti. U najmanje slučajeva sukob uzrokuje naplaćivanje zdravstvenih usluga, što je kao razlog za sukob navelo samo $19 \%$ ispitanika.

U nastavku smo ispitanicima ponudili tvrdnje o načinima komuniciranja između njih i medicinskih sestara, na koje su odgovarali ocjenama od 1 do 3 , pri čemu je 1 - ne slažem se, 2 - djelomično se slažem i 3 -slažem se.

Otkrili smo da je za uspješnu komunikaciju potrebno aktivno slušanje $(\bar{x}=2,93)$ i da je u komunikaciji između medicinske sestre i pacijenta povjerenje vrlo važno ( $\bar{x}=2,88)$. Stoga uspješna komunikacija dovodi do boljih i više postavljenih standarda pružanja zdravstvene skr- 


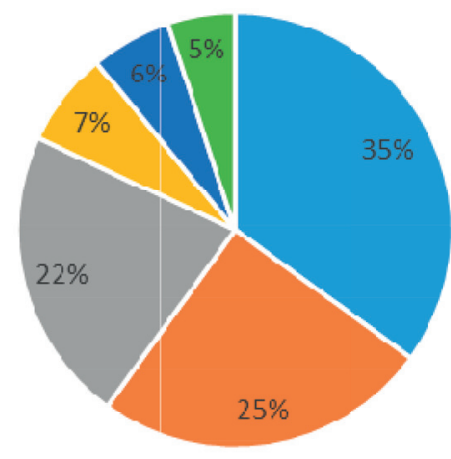

$$
\begin{array}{lll}
\text { - poštovanje } & \text { - ljubaznost } & \text { " povjerenje } \\
\text { - komunikativnost } & \text { = empatija } & \text { - svladavanjc sukoba }
\end{array}
$$

\section{Slika 3. Činitelji uspješne komunikacije $(\mathbf{N}=980)$}

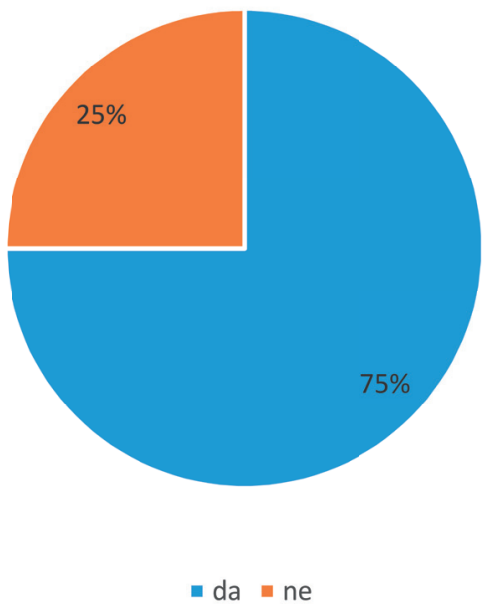

Slika 4. Sukobi s medicinskim sestrama $(\mathbf{N}=980)$

bi $(\bar{x}=2,87)$. Kada prilikom komuniciranja s pacijentom dolazi do sukoba potrebna je suradnja svih sudionika i zajedničko rješavanje problema $(\bar{x}=2,79)$. Također smo otkrili da se učinkovita komunikacija odvija kada ne postoje smetnje i poremećaji od strane pacijenta, medicinske sestre ili komunikacijskog kanala $(\bar{x}=2,63)$ te da u zdravstvu treba izbjegavati nastanak sukoba $(\bar{x}=2,56)$. Došli smo i do zaključka da nije moguće ne komunicirati $(\bar{x}=2,38)$ jer cijelo vrijeme održavamo verbalnu ili neverbalnu komunikaciju. Ispitanici smatraju da se poremećaji u komunikaciji javljaju prilikom prenošenja poruka $(\bar{x}=2,15)$ zbog brzih i dugih uputa te stoga što medicinska sestra upotrebljava stručnu terminologiju ( $\bar{x}=2,36)$. Neki poremećaji dovode do stvaranja sukoba, što nije ništa neuobičajeno jer sukob je dio komunikacije $(\bar{x}=2,27)$. Vrlo je važan dio komunikacije i empatija ( $\bar{x}=2,16)$. Istraživanje je također pokazalo da medicinska sestra pacijentima posvećuje premalo vremena za razgovor $(\bar{x}=2,08)$. Medicinska sestra mora biti svjesna da sukob nije uvijek loš za njezin odnos s pacijentom ( $\bar{x}=1,97$ ). Sukob može čak i poboljšati komunikaciju među njima. Medicinska sestra mora stavljati naglasak na verbalnu, kao i na neverbalnu komunikaciju, jer se u zdravstvu isprepliću i nadopunjuju, čega su svjesni i ispitanici, jer su odgovorili da verbalna komunikacija nije važnija od neverbalne $(\bar{x}=1,74)$. Sukob u komunikaciji 


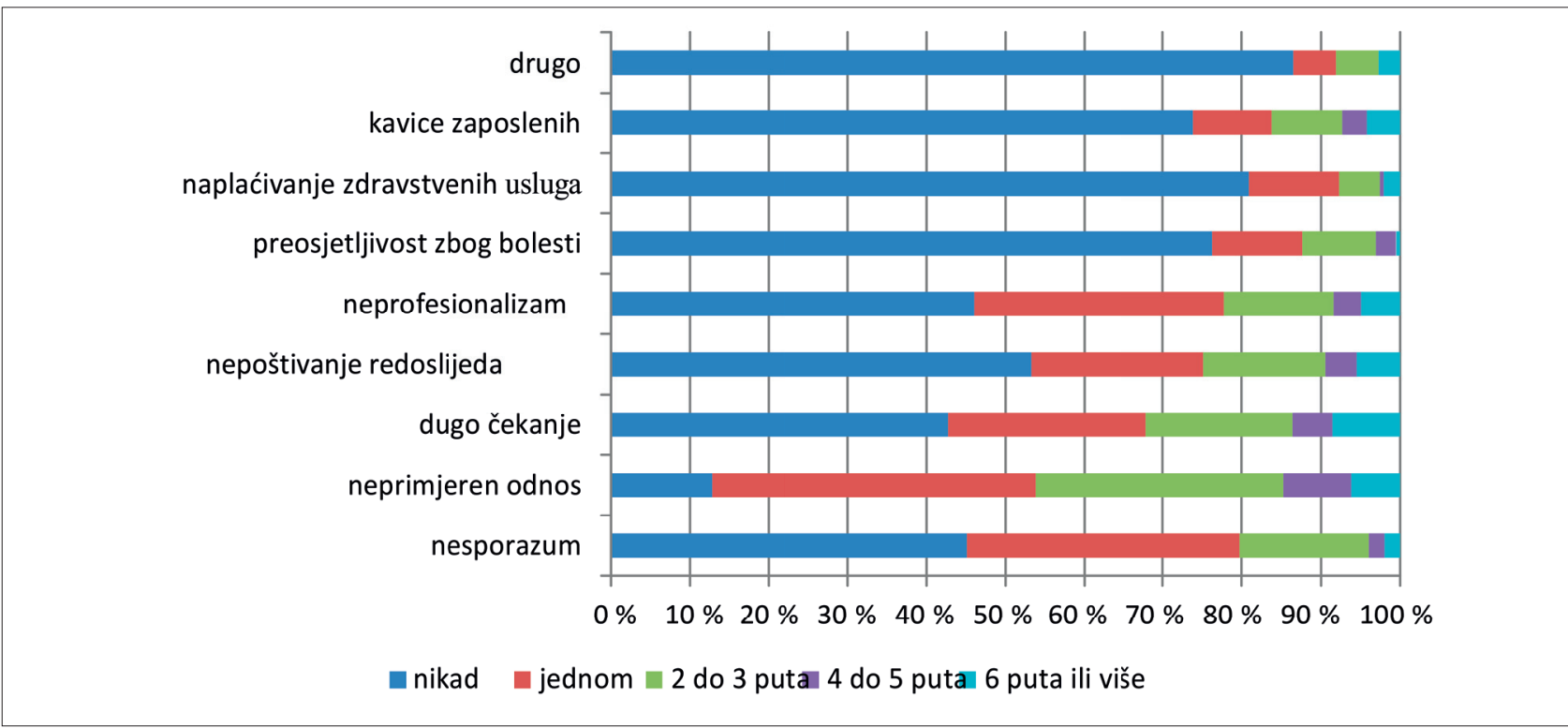

Slika 5. Razlozi sukoba s medicinskim sestrama $(\mathbf{N}=980)$

\begin{tabular}{|c|c|c|c|c|}
\hline TVRDNJE & 1 & 2 & 3 & $\bar{x}$ \\
\hline Diplomirana medicinska sestra pacijentu posvećuje premalo vremena za razgovor. & $12 \%$ & $67 \%$ & $21 \%$ & 2,08 \\
\hline Nije moguće ne komunicirati. & $19 \%$ & $24 \%$ & $57 \%$ & 2,38 \\
\hline Verbalna komunikacija u zdravstvu važnija je od neverbalne. & $40 \%$ & $45 \%$ & $15 \%$ & 1,74 \\
\hline $\begin{array}{l}\text { Povjerenje je vrlo važno u komunikaciji između diplomirane medicinske sestre i } \\
\text { pacijenta. }\end{array}$ & $0 \%$ & $16 \%$ & $84 \%$ & 2,88 \\
\hline Empatija nije urođena, međutim, možemo je naučiti. & $13 \%$ & $58 \%$ & $29 \%$ & 2,16 \\
\hline $\begin{array}{l}\text { Učinkovita komunikacija odvija se kada ne postoje smetnje od strane pacijenta, } \\
\text { diplomirane medicinske sestre ili kanala komunikacije. }\end{array}$ & $5 \%$ & $28 \%$ & $67 \%$ & 2,63 \\
\hline Za uspješnu komunikaciju potrebno je aktivno slušanje. & $0 \%$ & $7 \%$ & $93 \%$ & 2,93 \\
\hline $\begin{array}{c}\text { Uspješna komunikacija dovodi do boljih i više postavljenih standarda pružanja } \\
\text { zdravstvene skrbi. }\end{array}$ & $0 \%$ & $13 \%$ & $87 \%$ & 2,87 \\
\hline Poremećaji u komunikaciji najčešće se javljaju u prijenosu poruka (buka, kvar). & $9 \%$ & $67 \%$ & $24 \%$ & 2,15 \\
\hline $\begin{array}{l}\text { Poremećaji u komunikaciji javljaju se zbog brzih i dugih uputa tezbog toga } \\
\text { štodiplomirana medicinska sestra upotrebljava stručnu terminologiju. }\end{array}$ & $6 \%$ & $52 \%$ & $42 \%$ & 2,36 \\
\hline Sukob je dio komuniciranja. & $10 \%$ & $53 \%$ & $37 \%$ & 2,27 \\
\hline Sukob u velikoj mjeri nastaje zbog pacijenta. & $74 \%$ & $24 \%$ & $2 \%$ & 1,28 \\
\hline Sukob u velikoj mjeri nastaje zbog diplomirane medicinske sestre. & $79 \%$ & $21 \%$ & $0 \%$ & 1,21 \\
\hline Sukob je uvijek loš za odnos između diplomirane medicinske sestre i pacijenta. & $27 \%$ & $50 \%$ & $23 \%$ & 1,97 \\
\hline $\begin{array}{l}\text { Uspješno rješavanje sukoba zahtijeva suradnju svih sudionika i zajedničko rješavanje } \\
\text { problema. }\end{array}$ & $0 \%$ & $21 \%$ & $79 \%$ & 2,79 \\
\hline U zdravstvu treba izbjegavati nastanak sukoba. & $7 \%$ & $30 \%$ & $63 \%$ & 2,56 \\
\hline
\end{tabular}




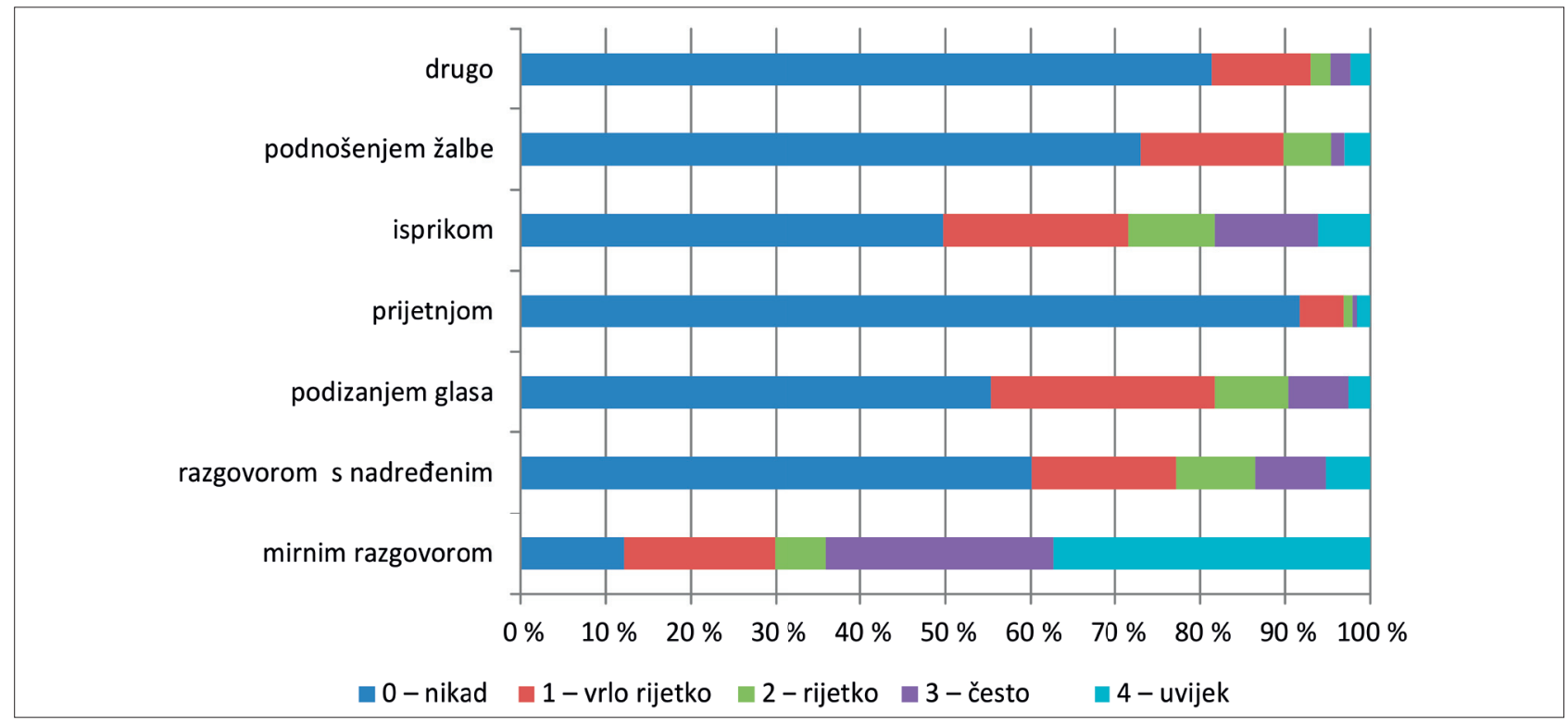

Slika 6. Načini rješavanja sukoba $(\mathbf{N}=980)$

mogu izazvati kako pacijent tako i medicinska sestra. U ovom istraživanju otkrili smo da se sukob u velikoj mjeri pojavljuje zbog pacijenta $(\bar{x}=1,28)$, međutim isto tako zbog medicinske sestre $(\bar{x}=1,21)$.

U nastavku istraživanja zanimalo nas je kako su ispitanici riješili nastali sukob.

Za $88 \%$ ispitanika miran je razgovor najučinkovitiji način rješavanja sukoba. Kao sljedeći učinkovit način rje- šavanja sukoba s medicinskim sestrama ispitanici su istaknuli ispriku (50\%). Potpuno suprotno, podizanjem glasa, sukob je riješilo $45 \%$ ispitanika. Kroz razgovor s nadređenima sukob je rješavalo $40 \%$ ispitanika. Neki su ispitanici sukob rješavali podnošenjem žalbe (27 \%) i prijetnjom (8\%). Međutim, ispitanici također navode druge načine kao što su: drugo mišljenje, zamjena liječnika i stomatologa.
Povećanje opsega elektroničkog poslovanja

Zapošljavanje dodatnih medicinskih sestara

Suradnja pacijenta pri svakom posjetu

Veća tolerancija

Manje impulzivno ponašanje

Svijest da nisam jedini pacijent

Veća strpljivost svih sudionika

Više ulaganja u vještine komunikacije

Više obavještavanja pacijenata o stanju

Rasterećivanje medicinskih sestara

$$
\begin{aligned}
& 0 \text { - ne bi smanjili } \\
& 2 \text { - rijetko bi smanjili }
\end{aligned}
$$

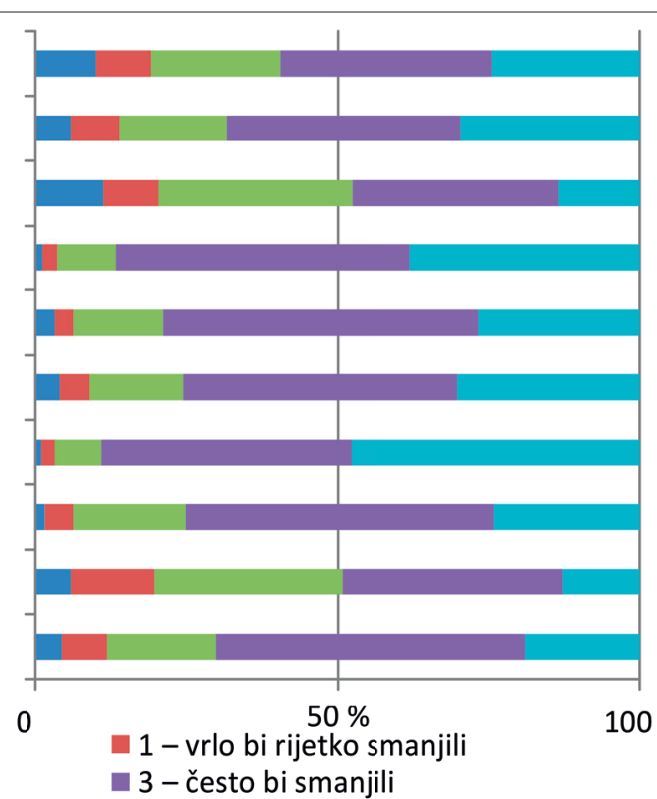

Slika 7. Činitelji koji bi smanjili sukobe između pacijenata i medicinske sestre $(\mathbf{N}=980)$ 
Također smo provjerili jesu li ispitanici ikad uočili kršenja svojih prava te zbog toga podnijeli pisnu žalbu. Tu je mogućnost iskoristilo $12 \%$ ispitanika, a $7 \%$ ispitanika požalilo se pravobranitelju za prava pacijenata.

$\mathrm{U}$ posljednjem dijelu istraživanja pitali smo ispitanike koji bi činitelji smanjili sukobe među njima i medicinskim sestrama.

Kao najbolju aktivnost za smanjenje konfliktnih situacija između medicinske sestre i pacijenata $48 \%$ ispitanika navodi veću strpljivost svih sudionika, $38 \%$ smatra da je to tolerancija, za $30 \%$ jednako su važne bile svijest pacijenta da nije jedini pacijent i zapošljavanje više medicinskih sestara. $11 \%$ ispitanika smatra da suradnja pacijenta pri svakom posjetu ne bi smanjila nastajanje sukoba, a $10 \%$ smatra kako bi se sukobi mogli smanjiti povećanjem elektroničkog poslovanja.

\section{Rasprava}

Komunikacija se upotrebljava u svakodnevnom životu u svim područjima rada i pomaže nam usklađivati misli, ideje, mišljenja i uspostavljati međusobne odnose. Komunikacija je važna za postizanje ciljeva koje si postavljamo bilo gdje: na poslu, kući ili u društvu ${ }^{19}$.

Poznavanje osnovnih zakonitosti i principa komunikacije predstavlja temelj za uspjeh u međusobnom komuniciranju između zdravstvenih djelatnika i pacijenata. Uzimajući u obzir principe komuniciranja međusobni će odnos zdravstvenih djelatnika s pacijentima biti takav da će bez straha i oklijevanja priopćavati svoje želje, potrebe i očekivanja ${ }^{20}$.

$\mathrm{U}$ ovom istraživanju otkrili smo da više od polovice ispitanika (59\%) procjenjuje komunikaciju između njih kao pacijenata i medicinskih sestara kao vrlo važnu odnosno važnu. Manje od polovice (48 \%) smatra da je komunikacija među njima i medicinskim sestrama često odnosno uvijek prikladna. Iz toga možemo zaključiti da sestre imaju premalo znanja o komunikaciji, krivo tumače upute nadređenih, podcjenjuju važnost informacija za pacijenta i kao rezultat toga pacijentu prenose nedovoljno važnih informacija o njegovu zdravstvenom stanju i sl. ${ }^{21}$

Različiti autori navode savjete za uspješnu komunikaciju medicinske sestre s pacijentom: upotrebljavajte jednostavne, razumljive izraze prilagođene dobi, obrazovanju i zanimanju, ponovite rečenicu ako je bila nerazumljiva, pokušajte biti nasmijani i direktni, nemojte biti previše ozbiljni i formalni, izbjegavajte upotrebljavati dijalekt ili medicinski žargon u razgovoru, najvažnije upute i savjete recite na početku razgovora s pacijentom i ponovite na kraju razgovora, provjerite je li pacijent zapamtio vaše upute i savjete tako da ga zamolite da vam ih ponovi, pročitajte pisane upute pacijentu i provjerite razumije li i ${ }^{22-24}$. Osim navedenih savjeta, za kvalitetan odnos između medicinske sestre i pacijenta također su važni toplina, poštovanje, iskrenost, ljubaznost, empatija, samorazotkrivanje, povjerenje, postavljanje pitanja, izražavanje mišljenja, humor, duhovnost i poznavanje osnovnih vještina komunikacije ${ }^{25}$. Naša su istraživanja pokazala i to da ispitanici u komunikaciji s medicinskim sestrama jako cijene poštovanje (35\%), ljubaznost ( $25 \%$ ) i povjerenje (22\%).

Kritike i nezadovoljstvo pacijenata obično su usmjereni na neprikladnu komunikaciju. Potreba za prikladnom komunikacijom i informiranošću kod pacijenata danas je u porastu, kao što se povećava i potreba za time da pacijenti sudjeluju u odlukama o vlastitom tijelu i liječenju. Ova se potreba pokazuje u povećanom bavljenju s tijelom, brizi o zdravoj prehrani i zdravom načinu života. Pacijenti koji su usmjereni prema zdravlju i zdravom načinu života još su osjetljiviji s obzirom na kvalitetu informacija koje dobivaju od liječnika, medicinskih sestara i ostalih zaposlenika u zdravstvenim ustanovama.

Velik broj medicinskih sestara ne sluša svoje pacijente i prekida ih, što dovodi do nedostatka informacija i poremećaja u komunikaciji. S obzirom na teške uvjete rada, mnoge su medicinske sestre pod pritiskom pa zato i ograničavaju svoje vrijeme s pojedinim pacijentima, što pak može dovesti do sukoba². Naši ispitanici već su bili u sukobu s medicinskim sestrama, što ih je potvrdilo čak $75 \%$, među kojima ima $10 \%$ onih koji se često nađu u sukobu. Baš zbog toga svi zaposlenici u zdravstvu moraju biti svjesni da svaki poremećaj u komunikaciji predstavlja veći rizik za pacijenta jer se tijekom liječenja može dogoditi da baš nedovoljna komunikacija i šumovi u komunikaciji koji se ponavljaju dovode do sukoba ${ }^{15,26}$.

Također nas je zanimalo koji su najčešći razlozi za sukobe među njima kao pacijentima i medicinskim sestrama. Kao razlog sukoba $87 \%$ ih navodi neprikladan odnos, $57 \%$ navodi dugo čekanje, a $55 \%$ različite nesporazume. Neprikladan odnos često proizlazi iz neznanja i možda čak nesposobnosti medicinske sestre da prihvaća način komuniciranja pacijenta i iz toga što ga zbog nedostatka vremena ne potiče na iskren razgovor ${ }^{27}$. 
Većina ispitanika (88 \%) rješava sukobe mirnim razgovorom, $50 \%$ smatra ispriku vrlo važnom, a $45 \%$ sukobe rješava podizanjem glasa. Za njih možemo reći da su naporni pacijenti koje medicinska sestra mora naučiti svladavati s pomoću svojeg stabilnog položaja, pravim pristupom i poznavanjem vještina rada s napornim pacijentima $^{28}$.

Među činiteljima koji bi smanjili sukob između medicinskih sestara i pacijenata navode veću strpljivost svih sudionika, toleranciju koja im omogućuje da izražavaju svoje potrebe i posebice osjećaj da imaju kontrolu nad vlastitim zdravljem i liječenjem ${ }^{11}$.

\section{Zaključak}

Rezultati prikazanog istraživanja provedenog na uzorku od 980 osoba pokazali su kako pacijenti doživljavaju proces komunikacije između medicinskih sestara i pacijenata, kao i uzroke za nastanak sukoba između njih. 59 \% pacijenata smatra da je komunikacija između medicinskih sestara i njih vrlo važna odnosno važna. Prilikom toga kao najvažnije činitelje komunikacije navode poštovanje (35\%), ljubaznost ( $25 \%$ i povjerenje (22\%). Uz to, naglašena je važnost aktivnog slušanja $(\bar{x}=2,93)$ i povjerenja $(\bar{x}=2,88)$. Također su svjesni da uspješna komunikacija dovodi do boljih i više postavljenih standarda pružanja zdravstvene skrbi $(\bar{x}=2,87)$.

Sukob s medicinskom sestrom već je doživjelo $75 \%$ ispitanika. Kao razlog sukoba najčešće navode neprimjeren odnos medicinske sestre (87\%), dugo čekanje (57\%), nesporazum (55\%) i neprofesionalnost medicinske sestre (54\%). Za većinu pacijenata ( $88 \%$ ) miran su razgovor ( $88 \%$ ) i isprika (55 \%) najuspješniji načini rješavanja sukoba. Kao najbolje aktivnosti za smanjivanje sukoba pacijenti navode veću strpljivost (48 \%) i toleranciju (38\%).

Rezultati istraživanja ukazuju na važnost komunikacije tijekom vođenja razgovora medicinske sestre s pacijentom. Samo će tako medicinska sestra biti u stanju nesmetano komunicirati s pacijentima. Time će također dovesti do toga da će pacijent razumjeti svoju bolest, da će se s njome moći nositi te također znati živjeti s njom, što je i svrha komunikacije između medicinske sestre i pacijenta.

\section{Literatura}

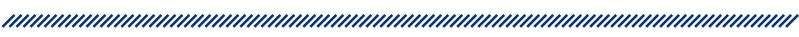

1. Brodarič M. Strokovni odnos zdravstvenih delavcev do pacientov. U: Filej B, ur. Celostna obravnava pacienta kako daleč smo še do cilja? Novo mesto: Zbornik prispevkov z recenzijo; 2012:7-16.

2. Wright KB, Sparks L, O'Hair D. Health communication in the 21st century. Chichester (West Sussex, UK): WileyBlackwell; 2013.

3. Prebil A, Mohar P, Drobne J. Komunikacija v zdravstvu. Celje: Celjska Mohorjeva družba: Društvo Mohorjeva družba; 2009.

4. Iršič M. Uvod v razreševanje konfliktov $v$ medosebnih odnosih. Ljubljana: Zavod Rakmo; 2005.

5. Rungapadiachy DM. Medosebna komunikacija v zdravstvu: teorija in praksa. Ljubljana: Educy; 2003.

6. Škerbinek L. Profesionalna komunikacija medicinske sestre. Zdravstveni obzornik. 1992;26 (1/2):29-32.

7. Svoljšak Š. Komunikacija z vidika Zakona o pacientovih pravicah (ZPacp). U: Matković M i Petrijevčanin B, ur. Komunikacija in njene vrzeli pri delu z onkološkim pacientom. Ljubljana: Sekcija medicinskih sester in zdravstvenih tehnikov v onkologiji pri Zbornici zdravstvene in babiške nege Slovenije; 2011:37-46.

8. Sotler R. Nekatere dileme medicinskih sester v zvezi z zakonom o pacientovih pravicah. U: Filej B, ur., Celostna obravnava pacienta - kako daleč smo še do cilja? Novo mesto: Zbornik prispevkov z recenzijo; 2012: 269-276.

9. Urh M, Lampe J, Tomažič $P$, Zevnik Rozman H. AIDS zaznamuje Afriko. Trajanus, d.o.o., Kranj; 2009.

10. Filipič I. Komunikacija v zdravstveni negi. Obzornik zdravstvene nege. 1998;32(5/6):221-225.

11. Webb L. Nursing:communication skills in practice. Oxford: Oxford University Press; 2011.

12. Edwards M. Communication skills for nurses: a practical guide on how to achieve successful consultations. London: Quay; 2010.

13. Rakovec-Felser Z. Psihologija telesnega pacienta in njegovega okolja. Maribor: Založba Pivec; 2009.

14. Ovijač D. Sodelovanje in profesionalna komunikacija v zdravstvu. U: Bračko V, ur. Urgentni pacient - včeraj, danes, jutri: zbornik predavanj / Zbornica zdravstvene in babiške nege Slovenije. Zveza strokovnih društev medicinskih sester, babic in zdravstvenih tehnikov Slovenije, Sekcija medicinskih sester in zdravstvenih tehnikov v urgenci, 3. mednarodni kongres, Terme Čatež, 15. in 16. oktober 2015. 2015:21-25.

15. Matković M, Zajc M, Pečan Slokar T, Bernot M. Ko komunikacijski šumi predstavljajo nevarnost za pacienta. U: Matković M i Petrijevčanin B, ur. Komunikacija in vrzeli pri delu z onkološkim pacientom. Ljubljana: Sekcija medicinskih sester in zdravstvenih tehnikov v onkologiji pri Zbornici zdravstvene in babiške nege-Zvezi strokovnih 
društev medicinskih sester, babic in zdravstvenih tehnikov. 2011:95-108.

16. Mumel D. Komuniciranje v poslovnem okolju. Maribor: De Vesta; 2008.

17. Mitrovič S. Komuniciranje in konflikti. Diplomsko delo. Koper: Univerza na Primorskem; Fakulteta za management Koper; 2006.

18. Brinkert R. A literature review of conflict communication causes, costs, benefits and interventions in nursing. Journal of Nursing Management. 2010;18(2):145-56. Dostupno na: http://web.ebscohost.com/ehost/pdfviewer/ pdfviewer?sid=2e3b8359-4a56-43f5-9114- 93dc13532ca0 \%40sessionmgr13\&vid=2\&hid=20 (pristupljeno 12. ožujka 2016.).

19. Kompare A, Stražišar M, Dogša I, Vec T, Curk J. Uvod v psihologijo. Učbenik za psihologijo v 2. letniku gimnazijskega in srednje tehniškega oz. strokovnega izobraževanja. Ljubljana: DZS; 2010.

20. Starc J. Komunikacija kot sredstvo izražanja pacientovih potreb. U: Filej B, ur. Celostna obravnava pacienta - kako daleč smo še do cilja? Novo mesto: Zbornik prispevkov z recenzijo. 2012:269-276.

21. Finke E, Light J, Kitko L. A systematic review of the effectiveness of nurse communication with patients with complex communication needs with a focus on the use of augmentative and alternative communication. Journal of clinical nursing. 2008;17(16):2102-15. Dostupno na: http://web. ebscohost.com/ehost/pdfviewer/pdfviewer?sid=aea618d6cb58-4bb2-a890-ff341c8e6605\%40sessionmgr10\&vid=11\&h id=24 (pristupljeno 17. ožujka 2016.).
22. Neubreg M, Veronek J, Uršolin-Trstenjak N, Kozina G. Razvijene komunikacijske vještine medicinske sestre - preduvjet za cjelovitu skrb pacijenta. U: Filej B, ur. Celostna obravnava pacienta - kako daleč smo še do cilja? Novo mesto: Visoka šola za zdravstvo Novo mesto. 2012:222-227.

23. Leskovic L. Komunikacija, ki zagotavlja zadovoljstvo pacienta in zaposlenih. U: Nose B, Jugovič B, ur. Medsebojni odnosi v zdravstveni negi: zbornik prispevkov / 6. dnevi Marije Tomšič, Dolenjske Toplice, 23. januar 2014. Novo mesto: Fakulteta za zdravstvene vede; 2014:28-34.

24. Rešetič J. Vpliv pohval in pritožb na dobre medsebojne odnose. U: Nose B, Jugovič B, ur. Medsebojni odnosi v zdravstveni negi: zbornik prispevkov / 6. dnevi Marije Tomšič, Dolenjske Toplice, 23. januar 2014. Novo mesto: Fakulteta za zdravstvene vede. 2014:56-67.

25. Balzer Riley, J. Communication in nursing. St. Louis (Missouri): Mosby Elsevier; 2008.

26. Kavčič B. Očrt poslovnega komuniciranja. Celje: Fakulteta za komercialne in poslovne vede; 2011.

27. Krečan N, Vrečko M. Komunikacija z laringektomiranim pacientom. U: Matković M, Petrijevčanin B, ur. Komunikacija in njene vrzeli pri delu z onkološkim pacientom: Zbornik predavanj. Maribor: Sekcija medicinskih sester in zdravstvenih tehnikov v onkologiji pri Zbornici zdravstvene in babiške nege - Zvezi strokovnih društev medicinskih sester, babic in zdravstvenih tehnikov Slovenije; 2011:114-121.

28. Ćurić Ž, Mejaš N, Kofol S. Reševanje konfliktov. U: Trampuž R, ur. Komunicirajmo med seboj. Nova Gorica: Društvo medicinskih sester in zdravstvenih tehnikov; 2005:46-58. 


\section{EFFECTIVE COMMUNICATION AND CONFLICT RESOLUTION BETWEEN A NURSE AND A PATIENT}

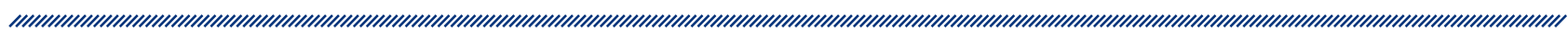

1 Jasmina Starc

1 Faculty of Health Sciences Novo mesto

\section{Abstract

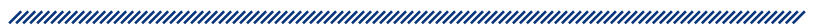

Communication is an essential part of providing medical care. It leads to higher and better standards of the provision of medical care. A nurse spends most of her time communicating with patients. The global aim of her professional communication with patients is a relationship in which she would enable them to communicate their needs, desires and expectations without fear and restraint. Good communication between a nurse and patients is a beneficial therapeutic procedure in itself, as it helps patients to express their physical and emotional needs; to ask questions and thus be more involved in the care that they are receiving; to feel that they are in control of their health and treatment; to develop trust and respect in the treatment process; and to become physically healthy. Nevertheless, problems do occur in the communication between the nurse and patients, which may lead to conflict situations. From the point of view of the nurse the most common causes of conflict are a lack of self-awareness and communication which has not been adjusted to the patients. From the point of view of the patients the most common causes of conflict situations are their fear, inability to express themselves, their misunderstanding of information and instructions, and their false expecta- tions. The paper presents the results of a research study which examined the experiences of patients in communicating with nurses. It has been established that $59 \%$ of the respondents consider communication with a nurse important or very important. $85 \%$ of them feel that communication between them and the nurses is often or always appropriate, owing to respect, kindness and trust. More than $10 \%$ of the respondents have had conflicts with nurses, which they resolved by talking calmly, apologising or even by raising their voice. They are aware, however, that the best activity for reducing conflict is patience from all those involved.

Keywords: patient, nurse, communication, conflict 